SCJR 14, no. 1 (2019): 1-10

\title{
The Enduring Controversy over the Mortara Case
}

\author{
DAVID KERTZER \\ david_kertzer@brown.edu \\ Brown University, Providence, RI 02912
}

When I published my book on il caso Mortara in 1997 I could never have imagined that, prompted by the publication of the book, over two decades later the case would receive such wide public attention and be the cause of renewed religious polemics involving Catholics and Jews. ${ }^{1}$ At the time I wrote The Kidnapping of Edgardo Mortara, the events had been largely forgotten, at least outside limited Jewish circles, and even there not much was known about it. In writing the book, in fact, one of the issues I addressed, albeit briefly, was why a historical event of great political consequence, one that at the time attracted such intense interest from California to Germany, and that involved the French Emperor and pleas to the American president, had been so thoroughly forgotten. ${ }^{2}$ Most of all I reflected on the fact that with very few exceptions, Italian historians had ignored the case and indeed most knew nothing about it when in fact it played a significant role in the key Italian drama of the nineteenth century, the Unification of Italy. ${ }^{3}$

The latest round of polemics came to a head in early 2018 with the publication in First Things of an article, "Non Possumus," by the Dominican Romanus Cessario, professor of theology at Boston's St John's Seminary, defending Pius IX's decision to send the papal police to seize the six-year-old Edgardo from his Jewish family and remove him into a Church institution. ${ }^{4}$ In responding to critics of that piece, Cessario suggests that my own account of that history was tendentious, writing: "If Catholics are to respond effectively to David Kertzer's allegations in The Kidnapping of Edgardo Mortara.... Evaluation of Pope Pius IX's actions ... should be based on the most accurate detailing of the facts that political, legal, and religious history can provide." What he suggests is the most accurate "detailing of the facts" comes from publication of an English edition last year of what is said to be the authentic account written by Edgardo Mortara him-

\footnotetext{
${ }^{1}$ A version of this article was given as the keynote address to the Annual Meeting of the Council for Centers on Jewish-Christian Relations at Providence College on November 4, 2018.

${ }^{2}$ David I. Kertzer, The Kidnapping of Edgardo Mortara (New York: Knopf, 1997). The book has now been published in eighteen languages.

${ }^{3}$ The most notable exception being Gemma Volli's series of articles on the Mortara case published in 1960 (Gemma Volli, “Il caso Mortara," Rassegna Mensile d'Israel, terza serie, vol. 26, no. 1/2, pp. 29-39; no. 3, pp. 108-12; no. 4, pp. 149-57; no. 5, pp. 214-21; no. 6, pp. 274-79.)

${ }^{4}$ Cessario, Romanus, O.P., "Non Possumus," First Things, February 2018, https://www.firstthings.com/article/2018/02/non-possumus.
} 
self of the controversial events surrounding Pius IX's actions. ${ }^{5}$ I will later turn to that text, but I would first like to put all this in a larger historical framework.

Indeed, one of the key elements of the enduring Mortara controversy has been the continuing failure to agree on the basic facts of the case, apart from any evaluation of whether what the principal players did was right or wrong, good or bad. It is true that some of the facts may never be fully known. In my book, I describe how from the very beginning, from the day that Edgardo was taken from his home in 1858, two competing narratives of the events developed and were spread by partisans. Defenders of the Church told of a boy who within hours of being liberated from his Jewish family saw the miraculous effects of his baptism work their wonders, as he begged the policeman who took him to Rome to stop at churches along the way so that he could kneel and pray to the Madonna. In this narrative, when Edgardo's parents came to visit him in the House of the Catechumens in Rome, he begged the rector to prevent them from returning, feeling threatened by them. On the other hand, the narrative that quickly appeared in the liberal and the Jewish press of the time told of a small child violently torn from his father's arms who went screaming into the police wagon, a child who when his parents visited him in Rome's House of the Catechumens begged them tearfully not to leave without taking him home to his brothers and sisters in Bologna.

The logic behind Father Cessario's premise seems on the face of it to be strong. English-speaking readers now have the account written by Edgardo Mortara himself of what happened to him, so past doubts about the events in question can be laid to rest. His First Things essay appropriately appears in the form of a review of that book, newly published by the Ignatius Press of San Francisco. ${ }^{6}$ What apparently neither Father Cessario nor the editors of Ignatius Press realized was that what they published was a significantly altered version of what Edgardo actually wrote, in Spanish, in the 1880s. I detail some of this in the piece I published last spring for The Atlantic and won't go into that story here. ${ }^{7}$ But let's assume that a fully faithful translation of the actual text prepared in the 1880s by Mortara had been published. How should we view the facts presented by the protagonist of the case himself?

From early on, Edgardo became one of the main composers of the narrative of what had happened to him at a young age. He would base much of his career as a preacher on crafting a stirring narrative of religious redemption as he traveled from country to country, the famous Edgardo Mortara, over whom a pope and an emperor once fought, revealing his true account of that dramatic tale.

\footnotetext{
${ }^{5}$ Cessario, Romanus, O.P. "Romanus Cessario replies," First Things, April 18, 2018, https://www.firstthings.com/article/2018/04/letters.

${ }^{6}$ Messori, Vittorio, Kidnapped by the Vatican? The Unpublished Memoirs of Edgardo Mortara (San Francisco, Ignatius Press, 2017).

${ }^{7}$ Kertzer, David I., "The Doctored 'Memoir' of a Jewish Boy Kidnapped by the Vatican," The Atlantic, April 15, 2018,

https://www.theatlantic.com/international/archive/2018/04/edgardo-mortara-doctoredmemoir/554948/.
} 
One of the earliest indications we have of the story that Edgardo told of his redemption from his Jewish family comes in a letter he wrote to Pius IX in 1871 paying homage to the pope on the $25^{\text {th }}$ anniversary of the his pontificate. There he tells the pope of his great feeling of gratitude: "I know very well, and others know too, all I owe to You for freeing me from the insanities of the Synagogue [dalle insanie della Sinagoga]... But God's enemies, who are the enemies of Yours and mine, saw in this only a reason for attacking Your Holiness with violent furor, to injure you, to scorn you, to insult you, and so the most noble and heroic actions came to be made to look bad, and reciprocated with the cruelest and most vile sarcasms." Mortara then went on to blast the founders of the new Italian state which had only the year before seized Rome from the pope to make it Italy's capital, denouncing the "perverted, iniquitous, foolish Liberators of Italy who know not what they are doing." He told the pope that the nation would be "infinitely happier and more pleased" to remain under his rule. ${ }^{8}$

Accounts of Mortara's sermons in his far-flung travels in the last decades of the nineteenth century, which he apparently gave in six different languages, offer some insight here. He gave a series of sermons during Lent in 1897 in Venice's San Marco basilica and subsequently had them published as a booklet. He waited until his last sermon to share his personal tale. "I will end," he said,

by satisfying your legitimate curiosity.... I was baptized by a young Catholic girl when I was still a child and gravely ill living in the bosom of my Jewish family and educated in the religion of my parents. I was ignorant of the fact that God's grace had touched and redeemed me. Six years later, the fact came to light, and Pope Pius IX... faithful to the tenets of divine law believed it his duty to place me, under his tutelage, in the heavenly nectar of Catholic truth. He entrusted me to the Director of the Neophytes, then to the Canons Regular, to which Order I belong today. Much noise was made in my name and about my baptism. Pius IX had to suffer much at the hands of the great and the little, as he used to say. But he remained firm, and firm I remained as well, firm in the grace that accompanied me. To all the temptations, the caresses, the flatteries of my relatives and strangers I responded: I am Christian, and I want to die a Christian. From that time grace persuaded me of the divinity of the [Christian] religion. Today I am convinced of it for another reason as well, because I have studied my religion and the others, and I would give my life to swear that only the Catholic religion is true. ${ }^{9}$

\footnotetext{
${ }^{8}$ A handwritten draft of Edgardo Mortara's letter is found in the historical archives of the Canons Regular, at San Pietro in Vincoli in Rome, fascicolo n. 7839, Mortara, Pio D., Bozza - "una canzone a Pio IX $-25^{\circ}$ del Ponteficato - 1871." I would like to thank the late Alessandro Visani for his help with work in the archives of the Canons Regular in Rome and in Gubbio.

${ }^{9}$ Mortara, Pio Maria, Sintesi delle Conferenze tenute nella Basilica Patriarcale di S. Marco e nella Chiesa di S. Moisè in Venezia dal P. D. Pio M.a Mortara, Canonico Regolare Lateranense, Dottore in Teologia-Missionario Apostolico (Venezia, Tip. Patriarcale già Cordella, 1897). A copy of the booklet is found in the historical archives of the Canons Regular, at San Pietro in Vincoli in Rome, A8936. An outraged, combative review of the pamphlet can be found in the April 1897 issue of $I l$ corriere israelitico, written by Rabbi Giuseppe Cammeo.
} 
As part of his efforts to use his inspiring story not only to convert the Jews but also to bring wayward Catholics back to the Church, Edgardo travelled later that same year to the United States. Hosted shortly after his landing with a sympathetic Catholic community in Brooklyn, he hastened to meet with New York's archbishop to get support for his work. Archbishop Michael Corrigan, the son of Irish immigrants to Newark, New Jersey, was less than pleased to encounter the famous Jewish convert, and, for reasons that will soon become clear, turned him down. But having done so he was nervous. At the time, the American church came under the responsibility of the Congregation for the Propaganda of the Faith in Rome, and, as Corrigan would write, he was worried that his actions might be cast in a negative light. In writing to Cardinal Mieczysław Ledóchowski, prefect of the Congregation of Propaganda Fide, shortly after Mortara's visit, he explained: "as Rev. Mortara is in the hands of these three or four priests, whose sympathies I do not enjoy, I have reason to suspect that some report will be sent either to the Vatican or to the S[acred] Congregation [of Propaganda Fide] regarding the matter. For this reason it is best that Your Most Reverend Eminence knows the true state of affairs." 10

The American archbishop's letter, dated December 17, 1897, is worth quoting at some length. He wrote it in Italian:

Your Eminence,

The Priest E[dgardo] Levi Mortara, well known in Europe and beyond, arrived within the past few days in New York. He came to visit me and spoke to me of establishing missions for Italians and preaching in the churches of the city and outside it.

I did not think it opportune to grant him the necessary permission, for I know from experience that it is very difficult to establish Italian missions, and I know how difficult it is to keep those already existing going....

In addition, I do not think it prudent for Rev. Mortara to go around preaching here and there, because the Jewish colony of New York is quite powerful both in political influence and in wealth, and it has friendly relations with Catholics. If the above-mentioned Priest were permitted to go around preaching, not only would the old stories end up being repeated in the newspapers, which would produce such a great outcry, and make such a bad impression in America to the detriment of the Church, but moreover the Catholics would lose the sympathy and the support of the Jewish colony, which would certainly not look kindly on the granting of such a privilege to such a priest.

\footnotetext{
${ }^{10}$ The Italian historian Giovanni Pizzorusso discovered the Corrigan letter in the Propaganda Fide archives in Rome (Nuova Serie, vol. 332 (1905), ff. 126r-127v) and published the text, written in Italian, in his 1998 article, "Il caso Mortara: due libri e un documento americano," Il Veltro XLII, 1-2, pp. 134-41.
} 
Archbishop Corrigan concluded by telling the Cardinal that before writing he had discussed the matter with the Apostolic Delegate to the United States (there was no nuncio then, given the lack of diplomatic relations with the U.S.), and the papal delegate "fully approved my ideas."

A couple of weeks after the New York archbishop wrote his letter, Edgardo himself penned a letter, again offering himself as the definitive source of any accurate account of his story. Mortara's letter was occasioned by one he had received from Isaac Feibel, a Jew in Louisville, who wrote to him after reading Graetz's, now classic, then new History of the Jews. ${ }^{11}$ Feibel was apparently troubled by Graetz's statement that in being taken from his parents and "brought up in the ways of Catholicism; he eventually learned to curse his parents and his race." Mortara wrote his reply to Feibel in English:

You will readily admit that as I am the person spoken of in "Gratz's History of the Jews" I can be more truly relied upon to give the particulars of my life than those whose minds were doubtlessly biassed [sic] by Jewish predjudices [sic]. I was born in Bologna Italy, where there existed a law forbidding the employment of Christian servants by those of the Jewish faith. This law of the state my parents violated and had naturally to suffer the consequences. It was not against my wish that I left my home knowing full well that a refusal to do so would be a resistance to law and authority. Pius IX was king of Italy and in carrying out the above named law to its logical consequences was acting with all due authority as has been testified to in the High Court of Bologna in 1859. ... Against the calumnious and offensive statement made by Gratz, that I learned to curse my parents I must solemnly protest. And on the contrary I assure that I have always had the deepest \& most devoted attachment for them, never forgetting that Jesus Christ the True Messiah never abolished the Ten Commandments of God. ${ }^{12}$

There are many aspects of Mortara's handwritten letter that are striking, but let me just cite one. It involves one of the first bones of contention in the Mortara case at the time. Did Edgardo leave his parents and siblings sobbing and distraught, or did he go happily. Here Mortara states: "It was not against my wish that I left my home knowing full well that a refusal to do so would be a resistance to law and authority." I leave to readers the question of whether this first-person recollection is credible. Edgardo was six years old at the time.

Having been rebuffed by the archbishop of New York, Mortara began a several-months-long trip through many American cities, eager to preach and inspire his listeners with his account of how he had been saved by divine intervention and rescued from his Jewish family. In Philadelphia in March, he gave an inter-

\footnotetext{
${ }^{11}$ Herman Graetz, History of the Jews, vol. 5, Philadelphia: Jewish Publication Society, 1895, pp. $700-1$.

${ }^{12}$ The original of Mortara's letter is to be found in the American Jewish Historical Archives in New York City.
} 
view to the local Catholic newspaper. That the world was still paying attention is evident from the fact that the text of the interview was picked up by the press in Europe as well. The version published by the Semaine religieuse, the weekly publication of the Lyon diocese in France, introduced the interview by heralding the fact that here was the person who could provide a true account of what had happened: "This is what he tells the reporter of the Catholic Standard, who asked him for the true story of his entry into the Catholic Church, as opposed to the imaginary fiction given by Jewry and accredited by all of the world's Masonry."

In his Philadelphia interview, after telling his story of what led the servant to baptize him, Mortara asserted that in the weeks before the papal police seized him word of his baptism had already begun to spread: "When I learned that I was Catholic, a strange impulse took hold of me, and I desired not to remain any longer in my parents' home, wanting to receive a Catholic education. My parents were practicing Jews, and did not want to listen to me." He continued:

I was then only seven years old [he was six], and the laws of the Papal States forced me to comply with my parents' wishes. It was not long before the Pope heard my exceptional case spoken of and of my parents' energetic opposition. He invited them to end this opposition; he insisted saying that, since I had been baptized, he was obliged to take care of my Catholic education. In this period the temporal power of the pope was at its full extent; my parents acquiesced. I went to Rome; but I was not, as it was said at that time, forced to do so.

Mortara continued his story, recalling that his parents came to Rome in an unsuccessful effort to get him to return home. He said that a friend of the family was present at one of these meetings and tried to convince him to go back to his family, using the argument: "The fourth commandment commands you to obey your father and your mother." To which, Mortara claims to have replied, "There are three other commandments that relate to my duties to God." Edgardo at that time would have recently celebrated his seventh birthday.

Hammering the point home, the French Catholic article ended its account by citing the conclusion of the Philadelphia Catholic publication. These are the "declarations made by the 'young Mortara' now around fifty years old; he is certainly more credible, when he speaks of that which regards him, than all the antiCatholic journals gathered in one Masonic whole."13

In fact, much of Mortara's account of what had happened to him is pure fiction. The story of his learning of his baptism weeks before the police arrived to take him is invention, as of course is the account of his desire to leave his parental home to become Catholic. The scene of his arguments with his parents over his desire to leave home is fictitious, as is his entire description of the pope's efforts to convince his parents to let him go. The moving scene of the family friend cit-

\footnotetext{
${ }^{13}$ Semaine religieuse du Diocèse de Lyon, mars 1898, pp. 306-7.
} 
ing the Ten Commandments is similarly an invention. In fact it would have been unthinkable for the papal authorities to allow a Jewish family friend into the House of Catechumens to see him.

We know much of this thanks to the several hundred pages of testimony about these events taken in early 1860 as part of the trial of the Inquisitor on charges of kidnapping Edgardo. In those records, we find lengthy testimony given by almost all of the principals involved in the taking of Edgardo from his family, including his father, his mother, the policeman who removed him from his parents, and indeed of the Inquisitor himself. In fact, this is a historical case where we have an excellent documentary record of what happened, available for anyone to consult in the state archives of Bologna. We also have many hundreds of contemporaneous documents on the case to be found both in the Vatican Secret Archives and in the historical archives of the Jewish community of Rome.

A decade after Mortara's visit to the United States, Catholic journals in Europe were still reporting his own inspiring, first-person accounts of his story. A long narrative in the 1908 bulletin of a French Catholic mission dedicated to the conversion of the Jews avidly reported on Mortara's latest telling of his story. It began by emphasizing the huge impact that the taking of the little boy had on the fate of the Church. Although the pope was acting in accordance with Church and civil law at the time (which of course were one and the same in the Papal States), the journal explained, "the enemies of the Pope were looking for a pretext to take away his crown and his temporal domains. This incident accelerated the evolution of political events, and the Princes, rising up against the Lord and against his Christ, provoked the people to break the yoke of the Pontifical theocracy."

The mission bulletin then returned to Mortara's own account, which, as he frequently did, he gave using the third person, in recollecting his early encounters with the Pope after his arrival in Rome: "Sometimes, seeing the boy at his feet, the innocent cause of the uprising of hell, [the Pontiff] cried out amidst his tears, 'Do you see this child here! The great and the small wanted to tear his soul away from me, but I said to all: "No, I cannot: Non possumus! To surrender a soul would be a great crime."'” And so, reported Mortara, recollecting after half a century these scenes in his first weeks in Rome, "Neither the tender entreaties of my dear parents, nor the most attractive promises succeeded" because "grace never abandoned me." "My response was always the same: I am Christian! If my parents would only become Christian too, then I would return to my family." The article concluded with what it described as Mortara's plea: "As the anniversary of my deliverance from the kingdom of darkness coincides with that of the brilliant triumph of the immaculate Virgin, I ask for prayers at Our Lady of Lourdes; prayers for me, for my dead parents, for my brothers who are still Jews, so that there fall from their eyes the thick veil that prevents them from recognizing the divine Redeemer." 14

\footnotetext{
14 “Association de Prières en Faveur d'Israël, Résumé du $3^{\mathrm{e}}$ Trimestre de l'année 1908." Annales de la Mission de N.-D. de Sion en Terre Sainte, bulletin n. 121 (Paris, Devalois, 1908), pp. 9-14.
} 


\section{The Recent Polemics}

I now turn to the recent polemics over the Mortara case, again looking especially at how the actual historical facts of the case have been distorted. Even before Steven Spielberg's announcement of his plan to make a film based on my book drew new attention to the story, Alfred Uhry's play based on the book triggered angry reaction from some of the usual suspects among the defenders of the Church of Pius IX (read: the Church before it took a wrong turn with the Second Vatican Council). ${ }^{15}$ In a piece titled, "Fact or Fiction: It's Catholic Bashing Just the Same," the Catholic League reacted to the book and play by charging: "Whether it's based on fact or fiction, or whether it's portrayed on the stage or on the screen, the Catholic bashers are a busy lot these days. They are as good at twisting the facts as they are at developing fictional accounts. Truth doesn't matter. What matters is results." 16 A similar script has been followed by the many bloggers of a similar persuasion in reacting to the Spielberg announcement of the planned film. As a typical passage in one of these puts it:

The Mortara case fell into obscurity shortly after the initial hubbub, except within Jewish circles, where it remained a cause celebre. It was obscure, that is, until the anti-Catholic Jewish historian David Kertzer published a book many feel is badly biased on the subject in 1997. ... Kertzer has written other hateful screeds alleging that Catholic popes played a significant role in the "rise" of anti-Semitism in Europe in the $19^{\text {th }}$ and $20^{\text {th }}$ centuries and also in the rise in fascism in the $20 \mathrm{~s}$ and $30 \mathrm{~s} .^{17}$

I could multiply my examples of such invectives, many referring to Mortara's own account of what had happened to him as the one accurate account of the case, comparing my own account unflatteringly to it. ${ }^{18}$ It is from this conservative matrix within the Church-identified with the opponents of Pope Francis - that the publication of what is represented as Mortara's own memoir sprang. Its Italian language publication in 2002 by Vittorio Messori, a man who coauthored books with both Popes John Paul II and Benedict XVI, was little noticed outside Italy. ${ }^{19}$ He offered the book as a direct response to my own, again

\footnotetext{
15 Alfred Uhry's play, Edgardo Mine, was performed at Hartford Stage in Hartford, Connecticut in 2002 and at the Guthrie Theatre in Minneapolis in 2006.

${ }_{16}$ https://www.catholicleague.org/fact-or-fiction-its-catholic-bashing-just-the-same/

17 "A Blog for Dallas Area Catholics", https://veneremurcernui.wordpress.com/2016/06/23/stevenspielberg-set-to-make-anti-catholic-diatribe-as-next-film/.

${ }^{18}$ Among many examples, see "The Truth about Edgardo Levi-Mortara," found on the web site of Our Lady Resistance, dating to 2014: http://ourladysresistance.org/antipope-francis.html.

Not surprisingly, some of these right-wing Catholic sites are openly anti-Semitic.

For an Italian example, see "Caso Mortara: la verità e la propaganda,"

https://www.ariannaeditrice.it/articolo.php?id articolo=58128. "The Jewish director Steven Spielberg is preparing a 'colossal' about the life of Don Pio Edgardo Mortara, which is being predicted to be only the latest of the many Jewish propaganda films produced in Hollywood."

${ }^{19}$ Vittorio Messori, “Io, il bambino rapito da Pio IX.” Il memoriale inedito del protagonista del 'caso Mortara' (Milan, Mondadori, 2005).
} 
claiming that the account he was publishing by Mortara himself would offer the fully accurate story. In an interview in Italy's leading newspaper, Il Corriere della Sera, following his book's Italian publication, Messori criticized those of us who had not relied on Mortara's account, saying that we ignored it "Because the 'true' Mortara, not the one used as a polemical weapon, never mattered to anyone. ${ }^{\prime 20}$

Yet dismissing what attempts to be as accurate an account of the events that a historian can achieve on the grounds that it does not take Mortara's own account as the gold standard is to fail to recognize that no account of the case is more partisan, and more constructed post facto, than that offered by Mortara himself.

As I mentioned earlier, in my recent Atlantic article I detailed both the ways in which Messori altered what Mortara actually did write in the text that Ignatius Press recently published, and the ways in which Mortara's 1880s original text itself misrepresents the history, so I won't repeat myself here. But let me offer one example, for those who may not have been following the recent polemics. I refer here to the way Ignatius Press has been advertising the book: Kidnapped by the Vatican? The Unpublished Memoirs of Edgardo Mortara. The publicists seize on a passage that indeed Messori makes much of in his lengthy introduction to the book, writing in their catalog copy for the book: "After several failed attempts to persuade his parents to enroll him in a local Catholic school, in 1858 Pope Pius IX had the boy taken from his family in Bologna and sent to a Catholic boarding school in Rome." In fact, no such attempts to persuade his parents to enroll Edgardo in a local Catholic school were ever made. Again, this is pure fiction, invented by Mortara himself. ${ }^{21}$

As you can imagine I have found these continuing attacks on my Mortara book to be upsetting. But I believe they may also be evidence of something much more important than my own ruffled feathers. When the Italian edition of my Mortara book came out two decades ago, it was reviewed in L'Avvenire, the most important Catholic newspaper in Italy, published by the Italian Church hierarchy itself. I could not have been more pleased with the review:

Despite the notoriety of the case, the story of Edgardo Mortara had not, until today, been object of specialized studies.... Kertzer reconstructs that event

\footnotetext{
20 "Non diffamate Pio IX il mio santo rapitore," interview by Aldo Cazzullo of Vittorio Messori, Corriere della Sera, 13 giugno 2005. A few days later, the same paper published a lengthy response to Messori in the form of an interview with Elèna Mortara, a descendant of the Mortara family and author of Writing for Justice: Victor Séjour, the Kidnapping of Edgardo Mortara, and the Age of Transatlantic Emancipations (Hanover: Dartmouth College Press, 2015). The article is titled "Il nostro avo bambino rapito e plagiato da Pio IX" (Corriere della Sera, 17 giugno 2005, p. 35).

${ }^{21}$ It is notable that Father Massimo Mancini, an Italian Dominican friar, in his recent piece on his fellow Dominican Pier Gaetano Feletti, the Bologna Inquisitor who directed the taking of Edgardo, points out this error in Mortara's account. He quotes the trial testimony of Feletti himself to the effect that Edgardo's parents only first heard of the alleged baptism when the carabinieri arrived at their home to remove Edgardo (Mancini, Massimo O.P. "Pier Gaetano Feletti e l'affare Mortara." pp. 42137 in Dominikaner und Junen/Dominicans and Jews, ed. by Elias H. Füllenback O.P. and Gianfranco Miletto (Berlin, De Gruyter, 2015)), pp. 426-27.
} 
in a manner that carefully attends to the motives of both sides.... The episode has been reconstructed with great finesse by David Kertzer, who recalls the great pain of the family, but also brings to light the strong personal tie that was established between Pius IX and the Jewish boy. The Pope kept him near him with paternal affection and closely followed the course of succeeding events.... Kertzer's book reveals the capacity to analyze Catholic motives and behaviors that were truly not easy for the Jews to understand....

And then, in its final paragraph, the review sums up: "In short, Kertzer's book efficaciously also shows how the historical analysis of painful events can contribute to promote a better reciprocal understanding between Christians and Jews." 22

Pardon me if I end on this immodest note. But I think it worth pondering the contrast between this 1997 Church view of the telling of the Mortara story, and the reactions we are seeing today. Are there forces now acting within the Catholic Church in opposition to Pope John Paul II's plea in the millennial year of 2000 for the Church and the sons and daughters of the Church, to come to a "cleareyed" understanding of the Church's past? Of course, there were always some in the Church who resented anyone - and here Catholic authors like Garry Wills and Jim Carroll were likely to be especially castigated-reporting unflattering aspects of Church history, and always some who rejected interreligious respect and understanding. But it is hard not to wonder whether the opponents of the sea change that the Second Vatican Council represented have not now taken up the Mortara case and fashioned it into a weapon to be used by those who see themselves as defenders of the true Church.

\footnotetext{
${ }^{22}$ Agostino Giovagnoli, ““Rapito’ da Pio IX,” Avvenire, 29 marzo 1997, p. 20.
} 